Minnesota Journal of Law \& Inequality

\title{
A Call to Congress: A Constitutional Indian Child Welfare Act is Not a Flawless Indian Child Welfare Act
}

Follow this and additional works at: https://lawandinequality.org/

Law \& Inequality: A Journal of Theory and Practice is published by the University of Minnesota Libraries Publishing.

\section{LIBRARIES}

P U B L I H I N G 


\title{
A Call to Congress: A Constitutional Indian Child Welfare Act is Not a Flawless Indian Child Welfare Act
}

\author{
Maci Burke†
}

In 1978, Congress enacted the Indian Child Welfare Act (ICWA), ${ }^{1}$ to regulate the removal and placement of Indian children in foster care, the termination of parental rights, preadoptive placement, and adoptive placement. ${ }^{2}$ The ICWA was enacted "to address rising concerns over 'abusive child welfare practices that resulted in the separation of large numbers of Indian children from their families and tribes through adoption or foster care placement, usually in non-Indian homes." 3 The ICWA refers to Native Americans as "Indians," thus, I will also refer to Native Americans as "Indians" to employ consistent language with the ICWA. The ICWA's stated purpose is to:

\begin{abstract}
protect the best interests of Indian children and to promote the stability and security of Indian tribes and families by the establishment of minimum Federal standards for the removal of Indian children from their families and the placement of such children in foster or adoptive homes which will reflect the unique values of Indian culture ....4
\end{abstract}

Unfortunately, Congress' goals of protecting Indian children while also maintaining Indian culture sometimes conflict. ${ }^{5}$ Most

†. J.D. Candidate 2021, University of Minnesota Law School; B.A. English \& Political Science 2018, University of Nebraska-Lincoln. I thank Professor Carol Chomsky for her guidance and feedback to make this Note the strongest possible. I am also thankful to the Minnesota Journal of Law and Inequality staff for all their edits and contributions. Finally, I thank my family and friends, specifically my mother, Trisha Burke, and my "brother," Dennis Metcalf, for their unwavering love and support throughout this process.

1. Indian Child Welfare Act, 25 U.S.C. $§ \S 1901-1963$.

2. 25 U.S.C. $\S 1903(1)$.

3. Brackeen v. Bernhardt, 937 F.3d 406, 416 (5th Cir. 2019) (quoting Miss. Band of Choctaw Indians v. Holyfield, 490 U.S. 30, 32 (1989)).

4. 25 U.S.C. $\S 1902$.

5. See Adoptive Couple v. Baby Girl, 570 U.S. 637, 638 (2013) (holding, in part, that the ICWA does not protect parents from involuntary termination of parental rights for Indian children where the parent never had custody of the child); Miss. 
recently, the ICWA has been challenged on Fourteenth Amendment equal protection grounds in Brackeen v. Bernhardt. ${ }^{6}$ Brackeen is the first case challenging the ICWA on equal protection grounds to be decided in a federal Circuit Court of Appeals. ${ }^{7}$ In Brackeen, the Fifth Circuit grappled with the ICWA's definitional boundaries, particularly whether the definition of an "Indian child" constitutes a race-based or political classification. ${ }^{8}$ Race-based classifications are subject to strict scrutiny review, ${ }^{9}$ while political classifications are subject to rational basis review. ${ }^{10}$ Because surviving strict scrutiny review is nearly impossible, ${ }^{11}$ a holding that the ICWA's "Indian child" definition ${ }^{12}$ is race-based, and subject to strict scrutiny, would likely result in a court overturning the ICWA in its entirety. ${ }^{13}$

While the U.S. District Court for the Northern District of Texas agreed with the plaintiffs in Brackeen, holding the ICWA unconstitutional, the Fifth Circuit disagreed, holding that the "Indian child" classification is political and constitutional. ${ }^{14}$ However, the Fifth Circuit has ordered the case be reheard en

Band of Choctaw Indians v. Holyfield, 490 U.S. 30, 51-53 (1989) (holding that children were domiciled on an Indian reservation despite a parent choosing to give birth off the reservation to facilitate their adoption by non-Indian parents, and that they would therefore still be covered under the ICWA umbrella); A.D. by Carter v. Washburn, 2017 WL 1019685, at *6-8 (2017) (dismissing equal protection challenges to the ICWA's active efforts provision, adoptive placement preferences, and burdens of proof for Indian child removal and termination of parental rights for lack of standing).

6. See Brackeen, 937 F.3d at 416.

7. See Kurtis A. Kemper, Annotation, Validity, Construction, and Application of Placement Preferences of State and Federal Indian Child Welfare Acts, 63 A.L.R.6th 429 (cumulative supp.) (originally published in 2011).

8. Brackeen, 937 F.3d at $426-29$.

9. Id. at 425 (citing Richard v. Hinson, 70 F.3d 415, 417 (5th Cir. 1995)).

10. Id. (citing Morton v. Mancari, 417 U.S. 535, 555 (1974)).

11. Fisher v. Univ. of Tex. at Austin, 758 F.3d 633, 664 (5th Cir. 2014) (discussing the stringency of strict scrutiny); see also Sarah Krakoff, Inextricably Political: Race, Membership and Tribal Sovereignty, 87 WASH. L. REV. 1041, 1055 n.57 (2012) (citing ERWin Chemerinsky, Constitutional LAW: PRINCIPLE AND Policies 671 (3d ed. 2006)) ("Strict scrutiny is virtually always fatal to the challenged law."); Douglas Linder, Levels of Scrutiny Under the Equal Protection Clause, UNIV. Mo.-KANSAS CITY: EXPLORING CONSTITUTIONAL CONFLICTS, http://law2.umkc.edu/faculty/ projects/ftrials/conlaw/epcscrutiny.htm [https://perma.cc/6J4N-DUSR] ("Usually, strict scrutiny will result in invalidation of the challenged classification . ...").

12. 25 U.S.C. $§ 1903(4)$.

13. See Brackeen, 937 F.3d at 426 (citing Morton v. Mancari, 417 U.S. 535, 552 (1974)) ("If these laws, derived from historical relationships and explicitly designed to help only Indians, were deemed invidious racial discrimination, an entire Title of the U.S. Code (25 U.S.C.) would be effectively erased and the solemn commitment of the Government toward the Indians would be jeopardized.").

14. Id. at $427-28$. 
banc. ${ }^{15}$ The question of whether the ICWA's definition of "Indian child" is a race-based or political classification will remain contested until the U.S. Supreme Court rules on the question, resolving how the balance will be struck between protecting Indian culture and enforcing the best interests of Indian children.

Part I of this Note discusses the background of the ICWA, including the history and policies behind the ICWA's adoption, judicial policies that resulted from the ICWA, and the ICWA U.S. Supreme Court cases. Part II examines the Fifth Circuit holding in Brackeen v. Bernhardt that the "Indian child" definition is a political, rather than race-based, classification, and argues that the Fifth Circuit correctly held that the "Indian child" definition is a political classification. Part III, however, notes the ICWA's "Indian child" definition, although constitutional as a political classification under the Equal Protection Clause, is flawed, requiring Congress to revisit the ICWA's "Indian child" definition.

\section{Background on the Indian Child Welfare Act}

The ICWA was implemented in response to a national trend of Indian children being removed from their homes at disproportional rates. ${ }^{16}$

\section{A. The Federal Government's Historical Treatment of Indian Children and Culture}

But we all survived, though at times the Indianness was almost beaten out of us. ${ }^{17}$

Before Congress implemented the ICWA to protect Indian children and culture, the federal government worked to "[k]ill the Indian, save the man" by replacing Indian traditional ways of life with American culture through forcefully removing and placing Indian children in boarding schools beginning in 1869. ${ }^{18}$ All in all,

15. Brackeen v. Bernhardt, No. 18-11479, 2019 WL 5847349 at*1 (5th Cir. Nov. 7, 2019) (per curiam). Oral arguments were heard in January, 2020. Julia Dreyer, Fifth Circuit Hears Oral Argument on ICWA Case, NAT'L COUNCIL OF URB. INDIAN HEALTH (Jan. 23, 2020), https://www.ncuih.org/policy_blog?article_id=345 [https://perma.cc/BKF3-7DQK].

16. S. REP. NO. 95-597, at 1 (1977).

17. Jon Reyhner, American Indian Boarding Schools: What Went Wrong? What is Going Right?, 57 J. AM. INDIAN EDUC. 58, 59 (2018).

18. See History and Culture: Boarding Schools, NATIVE PARTnershiP, 
the government operated as many as 100 boarding schools. ${ }^{19}$ Minnesota, for example, had sixteen boarding schools. ${ }^{20}$ The federal government left many Indian families no choice but to forfeit guardianship of their children for months and years on end. ${ }^{21}$ Many argue that the boarding schools were tools of ethnic cleansing. ${ }^{22} \mathrm{At}$ these boarding schools, Indian children were stripped of their Indian identities, forced to cut their hair, made to surrender their traditional clothing, forbidden from speaking their languages, told to forget their traditional religions, and taught about White American history. ${ }^{23}$ Indian children "were taught that their cultures were inferior." 24 Additionally, the children were often physically and sexually abused. ${ }^{25}$ And rather than returning the Indian children home to their families and tribes, "[i]t became standard policy ... to adopt them out to white families, all with an eye toward white acculturation." 26

After decades of such cruelty, Congress took some compensatory steps by enacting the Indian Reorganization Act (IRA) of 1934. The purpose of the Act was to "conserve and develop Indian lands and resources; to extend to Indians the right to form

http://www.nativepartnership.org/site/PageServer?pagename=airc_hist_boardingsc hools [https://perma.cc/PH9L-AS9E] (quoting Col. Richard Henry Pratt, founder of the Carlisle Indian School); Charla Bear, American Indian Boarding Schools Haunt Many, NPR (May 12, 2008), https://www.npr.org/templates/story/ story.php?storyId=16516865 [https://perma.cc/H6FZ-3NY5] (further quoting Pratt, who stated that "[a] great general has said that the only good Indian is a dead one ... [.] In a sense, I agree with the sentiment, but only in this: that all the Indian there is in the race should be dead. Kill the Indian in him, and save the man.").

19. See Bear, supra note 18.

20. See Denise K. Lajimodiere, The Sad Legacy of American Indian Boarding Schools in Minnesota and the U.S., MinnPosT (June 14, 2016), https://www.minnpost.com/mnopedia/2016/06/sad-legacy-american-indianboarding-schools-minnesota-and-us/ [https://perma.cc/XA8W-YBS4].

21. See Boarding Schools, NAT'L MUsEum OF THE AM. InDIAN, https://americanindian.si.edu/education/codetalkers/html/chapter3.html [https://perma.cc/4GFM-A5JG].

22. See, e.g, Reyhner, supra note 17 , at 72 .

23. See id.; Boarding Schools, supra note 21.

24. Boarding Schools, supra note 21.

25. Dan Gunderson, 'I've Never Told Anyone': Stories of Life in Indian Boarding Schools, MinN. PUB. RADIO (Oct. 3, 2019), https://www.mprnews.org/ story/2019/10/03/stories-of-life-in-indian-boarding-schools [https://perma.cc/Q3GTQRBJ] ("She started whispering about being sexually abused and she said, 'I don't know why I'm telling you. I have not told anybody.' Almost every survivor in the book experienced sexual abuse, or they witnessed it.").

26. See Lia Kvatum, Who Should Get to Adopt Native American Children?, WASH. PoST MAG. (Apr. 3, 2019), https://www.washingtonpost.com/news/magazine/ $\mathrm{wp} / 2019 / 04 / 03 /$ feature/who-should-get-to-adopt-native-american-children/ [https://perma.cc/CG48-AQMY] (quoting Matthew Fletcher, a Tribal Law expert and an Anishinaabe Indian). 
business and other organizations; to establish a credit system for Indians; to grant certain rights of home rule to Indians; [and] to provide for vocational education for Indians...."27 The IRA, however, still required Indians to replace their traditional ways of life by adopting White American culture. ${ }^{28}$ In fact, Indian historians have argued that " $[t]$ he IRA was the last great drive to assimilate the American Indian. It was also a program to colonize the tribes." 29

\section{B. Indian Child Welfare Act Statutory Provisions}

In 1978, after over a century of Indian children being removed from their families and culture, Congress responded by enacting the Indian Child Welfare Act. ${ }^{30}$ In enacting the ICWA, Congress recognized that a disproportionate number of Indian children were "separated from their natural parents through the actions of nontribal government agencies or private individuals or private agencies...."31 In particular, Congress found that in 1974 "approximately 25-35 percent of all Indian children are separated from their families and placed in foster homes, adoptive homes, or institutions." 32 Thus, the ICWA was enacted "to protect the rights of the Indian child as an Indian and the rights of the Indian community and tribe in retaining its children in its society." 33

i. Definitions

The ICWA defines an "Indian child" as "any unmarried person who is under age eighteen and is either (a) a member of an Indian tribe or (b) is eligible for membership in an Indian tribe and is the biological child of a member of an Indian tribe[.]" 34 The ICWA does not define tribal membership eligibility requirements. Further,

27. Indian Reorganization Act, ch. 576, 48 Stat. 984, 984 (1934) (codified at 25 U.S.C. $§ 5101)$.

28. See 1934: President Franklin Roosevelt Signs the Indian Reorganization Act, NATIVE VOICES, https://www.nlm.nih.gov/nativevoices/timeline/452.html [https://perma.cc/JKF2-JBD5] ("[I]n general the new tribal constitutions and bylaws were standardized and largely followed the Anglo-American system of organizing people. Traditional Indians of almost every tribe strongly objected to this method of organizing and criticized the IRA as simply another means of imposing white institutions on the tribes.").

29. See Tim Giago, Good or Bad? Indian Reorganization Act Turns 75, HuFFPost: BLOG (Sept. 13, 2009), https://www.huffpost.com/entry/good-or-badindian-reorga_b_284940 [https://perma.cc/7VB7-SKGY] (quoting Rupert Costo, Cahuilla historian, publisher, and journalist).

30. 25 U.S.C. $\S \S 1901-1963$.

31. S. REP. No. 95-597, at 1 (1977)

32. H.R. REP. NO. 95-1386, at 9 (1978).

33. Id. at 23 .

34. 25 U.S.C. $§ 1903(4)$. 
"Indian tribe" is defined as "any Indian tribe, band, nation, or other organized group or community of Indians recognized as eligible for the services provided to Indians by the Secretary because of their status as Indians ... [.]"35

\section{ii. Jurisdiction over ICWA Proceedings}

The ICWA imposes jurisdictional limits on "Indian child" custody proceedings. Indian tribes have sole jurisdiction regarding child custody proceedings over Indian children that fall within the definition of "Indian child" that are "domiciled within the reservation of such tribe, except where such jurisdiction is otherwise vested in the State by existing Federal law." 36 A state court lacks jurisdiction regarding foster care placement or termination of parental rights "in the absence of good cause to the contrary . ..." 37 If, however, a state court begins a legal proceeding regarding a foster care placement or termination of parental rights of an "Indian child," then that Indian child's tribe has the right to intervene in the proceeding at any point. ${ }^{38}$ Thus, to avoid tribal intervention in an involuntary state court proceeding regarding foster care placement or termination of parental rights, courts are required to notify the Indian child's family and tribe. ${ }^{39}$

\section{iii. Placement Preference}

The ICWA contains strict placement preferences for Indian families. In the event parents aim to put their child up for adoption, the parents' tribe may intervene and override their expressed wishes under the ICWA. ${ }^{40}$ An "Indian child" up for adoption, "in the absence of good cause to the contrary," shall be placed with: "(1) a member of the child's extended family; (2) other members of the Indian child's tribe; or (3) other Indian families." ${ }^{41}$ Likewise, strict placement preferences are implemented for "Indian child" foster care and preadoptive placements. ${ }^{42}$

35. § 1903(8).

36. § 1911(a).

37. § 1911(b).

38. $I d$.

39. § 1912(a).

40. § 1911(c) ("In any State court proceeding for the foster care placement of, or termination of parental rights to, an Indian child, the Indian custodian of the child and the Indian child's tribe shall have a right to intervene at any point in the proceeding."); Miss. Band of Choctaw Indians v. Holyfield, 490 U.S. 30, 36 (1989).

41. $§ 1915(\mathrm{a})$.

42. These preferences are as follows: 


\section{Tribal Enrollment Requirements}

Tribal enrollment requirements can broaden the number of "Indian children" and the scope of the ICWA. The U.S. Supreme Court has "recognized that Indian tribes have a right to define tribal membership as each tribe sees fit." 43 Historically, tribes have embraced eligibility mechanisms such as "[l]anguage, residence, cultural affiliation, recognition by a community, degree of 'blood,' genealogical lines of descent, and self-identification ...." ${ }^{44}$ Blood quantum is now the most generally used eligibility mechanism to determine tribal membership. ${ }^{45}$ For example, the Minnesota Chippewa Tribe requires a one-quarter blood quantum for tribal membership eligibility. ${ }^{46}$ Conversely, the Cherokee Nation does not rely on blood quantum. The tribe requires that the individuals must be either original enrollees listed on the Dawes Commission Rolls or descendants of said enrollees. ${ }^{47}$ Although many tribal eligibility requirements are more stringent than the Cherokee Nation's, tribes will likely amend their tribal eligibility requirements in the near future, making their eligibility requirements more lenient as blood quanta continue to dilute due to intermarriage. ${ }^{48}$ Thus, as time persists and tribes amend their tribal eligibility requirements, more and more Indian children will fall subject to the ICWA's "Indian child" definition.

(i) a member of the Indian child's extended family;

(ii) a foster home licensed, approved, or specified by the Indian child's tribe;

(iii) an Indian foster home licensed or approved by an authorized non-Indian licensing authority; or

(iv) an institution for children approved by an Indian tribe or operated by an Indian organization which has a program suitable to meet the Indian child's needs.

$\S 1915(b)$.

43. Matthew L.M. Fletcher, Tribal Membership and Indian Nationhood, 37 AM. INDIAN L. REV. 1, 1 (2012).

44. Nat'L Rsch. Council, Changing Numbers, Changing NeEds: American Indian Demography AND Public Health 105 (Gary D. Sandefur, Ronald R. Rindfuss \& Barney Cohen eds., 1996).

45. Id. at 106 ("Individuals enrolled in federally recognized tribes also receive a Certificate of Degree of Indian Blood... from the Bureau of Indian Affairs, specifying a certain degree of Indian blood, i.e., a blood quantum.”).

46. Minn. Chippewa Tribe EnRollment OrdinanCE § IV(A)(3) (2003).

47. Cherokee Nation Const. art. IV, $§ 1 ;$ see also Dawes Rolls, NAT'L ARChIVES (Oct. 4, 2016), https://www.archives.gov/research/native-americans/dawes/tutorial/ intro.html [https://perma.cc/8WD7-TDBJ] (Dawes Rolls "are the lists of individuals who were accepted as eligible for tribal membership in the 'Five Civilized Tribes': Cherokees, Creeks, Choctaws, Chickasaws, and Seminoles.").

48. NAT'L RSCH. COUNCIL, supra note 44 ("[I]t has been projected that within the next century, the proportion of those with a one-half or more blood quantum will decline to only 8 percent of the American Indian population, whereas the proportion with less than one-fourth blood quantum will increase to around 60 percent."). 


\section{The Existing Indian Family Exception}

Although the ICWA's definition of "Indian child" has not been amended since its enactment in 1978, states have attempted to limit its scope through the judicially-created "existing Indian family" exception. ${ }^{49}$ This exception originated in a 1982 Kansas Supreme Court case, In re Baby Boy L., where the court held that the ICWA did not apply to the proceeding because the ICWA's purpose is to protect an existing Indian family, and that Baby Boy L. was not part of an existing Indian family because his Indian father never had custody of him. ${ }^{50}$ After In re Baby Boy L., several more states adopted the "existing Indian family" exception, ${ }^{51}$ but Kansas has since overturned its precedent. ${ }^{52}$ In one case in particular, In re Bridget $R$., a California Court applied its own version of the existing family exception, holding that the ICWA was unconstitutional if its application was based solely on racial classification, but that it could be upheld if its application was based on race and other factors. ${ }^{53}$ Thus, the ICWA was constitutional if its application was based not only on a child's race but also whether the biological parents maintain a "significant social, cultural, or political relationship with the Tribe." 54 However, In re Bridget $R$. has been superseded and is no longer good law in California. ${ }^{55}$

The "existing Indian family exception" has been subject to much disagreement among the states. The exception is still valid law in Alabama, Indiana, Kentucky, Louisiana, Missouri, and Tennessee. ${ }^{56}$ In 2016, the Department of Interior expressly rejected the exception. ${ }^{57}$ The existence and use of the exception illustrates widespread attempts to limit the ICWA's application, while its

\footnotetext{
49. See ICWA Guide Online: Topic 1. Application, NAT'L INDIAN L. LIBR., https://narf.org/nill/documents/icwa/faq/application.html [https://perma.cc/KF9U$6 \mathrm{QYC}]$.

50. In re Baby Boy L., 643 P.2d 168, 174-75 (Kan. 1982).

51. See Rye v. Weasel, 934 S.W.2d 257 (Ky. 1996); In re Adoption of T.R.M., 525 N.E.2d 298 (Ind. 1988); In re Morgan, 1997 Tenn. App. LEXIS 818 (Tenn. Ct. App. 1997); Hampton v. J.A.L., 658 So. 2 d 331 (La. Ct. App. 1995); C.E.H. v. L.M.W., 837 S.W.2d 947 (Mo. Ct. App. 1992); S.A. v. E.J.P., 571 So. 2d 1187 (Ala. Civ. App. 1990).

52. See In re A.J.S., 204 P.3d 543 (Kan. 2009) (abandoning the court's application of the Existing Indian Family Exception due to the conflict between the exception and the ICWA language).

53. In re Bridget R., 41 Cal. App. 4th 1483, 1530 (Cal. Ct. App. 1996).

54. Id. at 1491.

55. In re Vincent M., 150 Cal. App. 4th 1247, 1251 (Cal. Ct. App. 2007) (abandoning the court's application of the Existing Indian Family Exception).

56. See supra note 51.

57. Indian Child Welfare Act Proceedings, 81 Fed. Reg. 114, 38782 (June 14, 2016) (to be codified at 25 C.F.R. pt. 23) (stating that the existing Indian family exception "has no basis in ICWA's text or purpose").
} 
rejection in other states shows such limitations remain controversial. Brackeen v. Bernhardt, however, presents the U.S. Supreme Court with the opportunity to resolve both the growing definitional issues and the validity of the existing Indian family exception. ${ }^{58}$

\section{E. United States Supreme Court ICWA Cases}

The U.S. Supreme Court has heard two cases involving the ICWA. 59 These cases, Miss. Band of Choctaw Indians v. Holyfield (Holyfield) and Adoptive Couple v. Baby Girl (Adoptive Couple), were decided over two decades apart. The cases illustrate the Court's changing views of the ICWA's applicable scope. ${ }^{60}$

In Holyfield, an unwed mother and father, both enrolled members of the Mississippi Band of Choctaw Indians, conceived twins. ${ }^{61}$ However, the couple purposefully gave birth over two hundred miles away from the reservation and voluntarily placed the twins up for adoption. ${ }^{2}$ The twins were adopted by a non-Indian couple and soon after, the Mississippi Band of Choctaw Indians tribe intervened, moving to vacate the adoption decree on grounds that under the ICWA, tribal courts shall have exclusive jurisdiction regarding Indian children. ${ }^{63}$ The biological parents argued that the ICWA did not apply because the children were born off of the reservation, and thus were never domiciled on the reservation as the Act requires. ${ }^{64}$ Domicile is not defined in the ICWA, and therefore the Court considered the domicile definition, ultimately holding that the twins were domiciled on the reservation, and that the Tribe had jurisdiction. ${ }^{65}$ Here, the ICWA overrode the parents' wishes to put their children up for adoption. The Court's broad interpretation of domicile strengthened tribal rights under the ICWA by allotting tribal jurisdiction over a larger range of "Indian children."

58. See Brackeen v. Bernhardt, 937 F.3d 406 (5th Cir. 2019).

59. See Miss. Band of Choctaw Indians v. Holyfield, 490 U.S. 30 (1989); Adoptive Couple v. Baby Girl, 570 U.S. 637 (2013).

60. Holyfield, 490 U.S. at 51-53 (broadening the ICWA's scope by adopting an expansive definition of "domicile," giving Indian tribes jurisdiction over more Indian child proceedings); Adoptive Couple, 570 U.S. at 649-51 (narrowing the ICWA application of termination of parental rights by holding, in part, that the ICWA does not protect parents from involuntary termination of parental rights for Indian children where the parent never had custody of the child).

61. Holyfield, 490 U.S. at 32.

62. Id. at 37,51 .

63. Id. at 38 .

64. Id. at 39

65. Id. at 53 . 
Conversely, in Adoptive Couple v. Baby Girl, the Court restricted some tribal powers under the ICWA. In Adoptive Couple, a baby girl who was $1.2 \%$ Cherokee was classified as an "Indian child" under the ICWA because she met the Cherokee tribe's eligibility requirement. 66 The child's biological mother and father were unwed, and the biological father was a member of the Cherokee Nation. 67 The biological father, even though capable, provided no financial assistance to the biological mother or child. 68 The biological father relinquished his parental rights via text message before the child's birth. ${ }^{69}$ The biological mother voluntarily put the child up for adoption, and the child was adopted by a nonIndian couple. ${ }^{70}$ The biological father objected to the adoption on grounds that ICWA $\S \S 1912(\mathrm{~d})^{71}$ and (f) ${ }^{72}$ bar the termination of his parental rights. ${ }^{73}$ The Court rejected the biological father's arguments because $\S 1912(\mathrm{f})$ applies to situations of "continued custody," but here, the biological father never had custody of the child. ${ }^{74}$ Additionally, § 1912(d) "applies only in cases where an Indian family's 'breakup' would be precipitated by the termination of the parent's rights." ${ }^{5}$ Here, the biological mother and father were already separated; therefore, the breakup had "long since occurred."76

Unlike in Holyfield, in Adoptive Couple, the Court limited the ICWA's applicability by applying a narrow reading of the Act's provisions. While Adoptive Couple does not overturn Holyfield, it indicates that the Court may have changed its perception of the ICWA's scope. As more constitutional challenges to the ICWA arise,

66. Adoptive Couple v. Baby Girl, 570 U.S. 637, 641 (2013).

67. Id. at $643-44$.

68. $I d$. at 637 .

69. Id. at 643 .

70. Id. at $643-44$.

71. 25 U.S.C. § 1912(d) (1978) ("Any party seeking to effect a foster care placement of, or termination of parental rights to, an Indian child under State law shall satisfy the court that active efforts have been made to provide remedial services and rehabilitative programs designed to prevent the breakup of the Indian family and that these efforts have proved unsuccessful.").

72. § 1912(f) ("No termination of parental rights may be ordered in such proceeding in the absence of a determination, supported by evidence beyond a reasonable doubt, including testimony of qualified expert witnesses, that the continued custody of the child by the parent or Indian custodian is likely to result in serious emotional or physical damage to the child.").

73. Adoptive Couple, 570 U.S. at 647.

74. Id. at 648 .

75. $I d$. at 651 .

76. Id. at 652 . 
such as that in Brackeen v. Bernhardt, how the Court interprets the ICWA's scope may determine the Act's constitutionality.

\section{The Fifth Circuit Court of Appeals' Holding in Brackeen $v$. Bernhardt Should Be Upheld upon the Rehearing en Banc}

This section does two things. First, it outlines the District Court's and the Fifth Circuit's holdings as well as explains racebased and political classifications. Second, it argues that the Fifth Circuit should uphold its decision upon its rehearing of Brackeen en banc because statutory text, legislative history, and prior U.S. Supreme Court case law support the Fifth Circuit's original decision holding the definition of "Indian child" is a political classification and therefore constitutional.

The Brackeen plaintiffs consisted of three families seeking adoption of Indian children who were denied because the children fell under the ICWA umbrella. ${ }^{77}$ The three couples struggling to adopt Indian children brought a Fifth Amendment equal protection challenge to the ICWA, arguing that the ICWA's definition of "Indian child" is a race-based classification and therefore unconstitutional. ${ }^{78}$ Underlying the plaintiffs' argument in Brackeen is the idea that the definition of "Indian child" is overly broad and does not effectively work in the best interests of the child or of Indian culture as Congress originally intended. The District Court held that the ICWA's definition of an "Indian child" is race-based, and therefore, subject to strict scrutiny. ${ }^{79}$ The Fifth Circuit reversed the District Court's decision, holding that the ICWA's "Indian child" definition was a political classification, and therefore, subject to rational basis review. ${ }^{80}$ This Note argues that the Fifth Circuit's original holding should be affirmed when it is reconsidered en banc.

\section{A. Political Classifications v. Race-Based Classifications}

Challenges under equal protection analysis are considered under strict scrutiny, intermediate scrutiny, or rational basis review, depending on the nature of the classification. ${ }^{81}$ Race-based

77. Brackeen v. Bernhardt, 937 F.3d 406, 418-20 (5th Cir. 2019).

78. Id. at $425-26$.

79. Brackeen v. Zinke, 338 F. Supp. 3d 514, 534 (N.D. Tex. 2018).

80. Bernhardt, 937 F.3d at 429.

81. Kristapor Vartanian, Equal Protection, 9 GEO. J. GENDER \& L. 495, 498 (2008). Some argue there is also a "fourth level of scrutiny, "rational basis with bite." Id. at 531 (citation omitted). 
classifications are subject to strict scrutiny review, ${ }^{82}$ while political classifications are subject to rational basis review. ${ }^{83}$ In Brackeen, the District Court and the Fifth Circuit classified the ICWA's definition of "Indian child" differently. The Northern District of Texas District Court based its race-based classification holding on the premise that the ICWA's definition of "Indian child" is a "blanket exemption for Indians," 84 which mirrors Rice v. Cayetano, not Morton v. Mancari. In Rice, the Court overturned a Hawaiian voting statute which restricted voter eligibility to only "native Hawaiians" and those with Hawaiian ancestry for positions in a state agency. ${ }^{85}$ The Rice Court held that the voting preference "used ancestry as a racial definition and for a racial purpose." 86 In Mancari, a Bureau of Indian Affairs (BIA) Indian hiring preference which "applies "only to members of "federally recognized" tribes," and "operates to exclude many individuals who are racially to be classified as 'Indians," 87 was upheld as a political classification. ${ }^{88}$ The U.S. Supreme Court limited the Mancari holding, recognizing that applying its decision more broadly would raise the "obviously more difficult question that would be presented by a blanket exemption for Indians." 89 Because an Indian child may be considered an "Indian child" under the ICWA's definition due to tribal eligibility, ${ }^{90}$ rather than actual tribal affiliation, ${ }^{91}$ the District Court found that the ICWA's definition of "Indian child" "uses ancestry as a proxy for race" 92 and is, therefore, a race-based classification, like Rice.

The Fifth Circuit reversed the District Court, holding that the ICWA's definition of "Indian child" is a political classification, subject to rational basis review. ${ }^{93}$ The Fifth Circuit employed four main arguments. First, Congress maintains broad power to regulate Indians and Indian tribes both on and off the reservation. ${ }^{94}$

82. Zinke, 338 F. Supp. $3 d$ at 534.

83. Bernhardt, 937 F.3d at 429.

84. Zinke, 338 F. Supp. 3d at 533 (quoting Morton v. Mancari, 417 U.S. 535, 554 (1974)).

85. Id. at 532 .

86. Id. (quoting Rice v. Cayetano, 528 U.S. 495, 517 (2000)).

87. Morton v. Mancari, 417 U.S. 535, 553 n.24 (1974).

88. Id. (quoting Mancari, 417 U.S. at 555).

89. Id. at 533 (quoting Mancari, 417 U.S. at 554).

90. 25 U.S.C. $§ 1903(4)$.

91. Mancari, 417 U.S. 535, 538 (1974) (stating the BIA hiring preference that was based on tribal affiliation).

92. Zinke, 388 F. Supp. 3d at 534.

93. Brackeen v. Bernhardt, 937 F.3d 406, 429 (5th Cir. 2019).

94. Id. at 428 . 
Second, the "eligibility" qualifier in the ICWA's definition of "Indian child" does not subject all Indian children to the ICWA's jurisdiction; therefore, the "Indian child" definition is not based solely on tribal ancestry or race. ${ }^{95}$ Because the ICWA reserves Indian tribes the right to determine tribal eligibility requirements, tribes have the freedom to determine to whom they offer membership. Thus, tribes may elect to admit members without Indian blood, or tribes may choose to not admit certain Indian persons because they do not fall within the tribal membership requirements. Third, the ICWA, unlike the voting preference law in Rice, is a federal law congressionally enacted to protect Indian children and tribes. ${ }^{96}$ Fourth, the state election preferences in Rice were state affairs, while ICWA adoption proceedings are affairs involving states, tribes, and Congress. ${ }^{97}$ Due to these considerations, the Fifth Circuit overturned the District Court decision and held that the ICWA's definition of "Indian child" is a political classification subject to rational basis review. ${ }^{98}$

The courts' different decisions classifying the ICWA's definition of "Indian child" are crucial because whether the definition is classified as race-based or political is dispositive. Under the Equal Protection Clause, political classifications are subject to rational basis review, while race-based classifications are subject to a higher standard of review, strict scrutiny review. ${ }^{99}$ Application of strict scrutiny review requires courts to determine whether the classification at issue is narrowly tailored to serve a compelling governmental interest. ${ }^{100}$ Surviving strict scrutiny review is nearly

95. Id. at 429

96. Id.

97. Id.

98. $I d$.

99. Loving v. Virginia, 388 U.S. 1, 11 (1966) (citing Hirabayashi v. United States, 320 U.S. 81, 100 (1943); Korematsu v. United States, 323 U.S. 214, 216 (1944)) (repudiating '“[d]istinguishing between citizens solely because of their ancestry,' as being 'odious to a free people . . ." and emphasizing that, therefore, "the Equal Protection Clause demands that racial classifications . . . be subjected to the "most rigid scrutiny"). See also Bernhardt, 937 F.3d. at 425 (explaining that while challenges to a state statute on equal protection grounds are brought under the Fourteenth Amendment, challenges to a federal statute on equal protection grounds are brought under the Fifth Amendment Due Process Clause, in which the Equal Protection Clause is implicitly included).

100. Adarand Constructors, Inc. v. Pena, 515 U.S. 200, 235 (1995) (referencing Fillilove v. Klutznick, 448 U.S. 448, 496 (1980) (concurring opinion)) ("Our action today makes explicit [that] ... Federal racial classifications, like those of a State, must serve a compelling governmental interest, and must be narrowly tailored to further that interest."). 
impossible. ${ }^{101}$ Conversely, a statute is considered a political classification if it is based on political characteristics and legitimate non-racial goals, such as protecting tribal sovereignty. ${ }^{102}$ Political classifications are subject to rational basis review. ${ }^{103}$ Rational basis review only requires a rational justification for the statutes be provided-it is a low bar. ${ }^{104}$ Thus, a holding that the ICWA's "Indian child" definition is a racial classification will likely find the ICWA, in its entirety, unconstitutional, whereas its classification as politically-based will preserve the Act's constitutionality. ${ }^{105}$

\section{B. The ICWA's "Indian Child" Definition Is a Political Classification}

Despite the ICWA's faults, this Article concludes that the "Indian child" definition is a political rather than a racial classification. ${ }^{106}$ The Fifth Circuit correctly examined U.S. Supreme Court precedent and the history of government special treatment of Indian affairs in Brackeen v. Bernhardt. ${ }^{107}$ The ICWA's statutory text, legislative history, and U.S. Supreme Court precedent support the Fifth Circuit's initial holding that the ICWA's "Indian child" definition is a political classification.

i. Statutory Text

The ICWA's statutory text advances the argument that the ICWA's definition of "Indian child" is a political, not racial, classification. The ICWA states "that Congress ... has assumed the responsibility for the protection and preservation of Indian tribes and their resources"108 and that the ICWA's purpose is to "protect the best interests of Indian children and to promote the stability

101. See discussion supra note 11.

102. Morton v. Mancari, 417 U.S. 535, 554 (1974) (classifying a BIA hiring preference as politically-based because the "preference is reasonably and directly related to a legitimate, nonracially based goal").

103. Bernhardt, 937 F.3d at 425.

104. See Mass. Bd. of Ret. v. Murgia, 427 U.S. 307 (1976) (applying rational basis review and upholding a statute because defendant must only show that the statute is rational).

105. Bernhardt, 937 F.3d at 426 (quoting Mancari, 417 U.S. at 552) ("If these laws, derived from historical relationships and explicitly designed to help only Indians, were deemed invidious racial discrimination, an entire Title of the United States Code (25 U.S.C.) would be effectively erased and the solemn commitment of the Government toward the Indians would be jeopardized.").

106. See id. at 429 .

107. Id. at $426-29$.

108. 25 U.S.C. $§ 1901(2)$. 
and security of Indian tribes and families . . .."109 These statements establish Congress' broad interest and assertion of duty to Indian culture and welfare that motivated the ICWA's enactment. It is these non-racial goals that were the driving force leading to the enactment of the ICWA.

The operative provisions of the statute reflect the same nonracial purpose. First, the ICWA favors placement with extended family and tribal members so placements "reflect the unique values of Indian culture...."110 Family is a core element in Indian cultures. ${ }^{111}$ In many Indian communities, the responsibilities of educating and caring for youth is shared by parents, extended family, and the entire community. ${ }^{112}$ Indian homes are often multigenerational, housing great-grandparents, grandparents, parents, and children. ${ }^{113}$ Retaining children within their extended family and tribe is of utmost importance to Indian cultures. ${ }^{114}$ Accordingly, the ICWA's placement preferences help Congress achieve its goal to protect and promote stability in Indian culture.

Second, the ICWA's definition of "Indian child" allots tribes, rather than Congress, discretion to identify parameters for defining an "Indian child." 115 The definition states that a child will be considered an "Indian child" if the child meets tribal eligibility requirements. ${ }^{116}$ The ICWA, however, does not define tribal eligibility requirements. Each tribe maintains discretion to determine its own tribal membership requisites. "Among tribal nations in the U.S., many different enrollment requirements

109. Id. $\$ 1902$.

110. Allison Krause Elder, "Indian" as a Political Classification: Reading the Tribe Back into the Indian Child Welfare Act, 13 Nw. J.L. \& Soc. POL'Y 417, 421 (2018) (quoting 25 U.S.C. § 1902).

111. See Paul Boyer, Young and Old Alike: Children and the Elderly Are a Priority in Native American Cultures, 3 J. AM. INDIAN Higher EDUC. 4 (1992), https://tribalcollegejournal.org/young-alike-children-elderly-priority-nativeamerican-cultures/ [https://perma.cc/97DE-TWQY] (describing some typical family dynamics in Indian cultures).

112. Id.

113. Living Conditions, NATIVE AM. AID, http://www.nativepartnership.org/site/ PageServer?pagename=naa_livingconditions [https://perma.cc/L6T4-7DUE].

114. H.R. REP. NO. 95-1386, at 9-10 (1978).

115. The ICWA does not set tribal membership requirements, so part (b) of the "Indian child" definition may be as expansive as tribes desire. See 25 U.S.C. $\S$ 1903(4).

116. Id. 
exist," 117 including blood quantum, ${ }^{118}$ lineal descendancy, ${ }^{119}$ and residency. ${ }^{120}$ As discussed by the Fifth Circuit in Brackeen, tribes may restrict or extend membership to any spectrum of children: children without any Indian blood may be extended tribal membership and children with one-quarter Indian blood quantum may be denied membership. ${ }^{121}$ The ICWA's definition of "Indian child" is not a hardline racial or ancestral limitation and is, therefore, not a racial classification. Additionally, offering Indian tribes a voice in defining their people recognizes tribes' sovereignty, promoting the stability of Indian tribes.

Third, Congress secured Indian tribes the right to intervene and reverse a mutually settled adoption of an "Indian child," further protecting tribal sovereignty and cultural connection. ${ }^{122}$ To ensure the right of intervention, the ICWA mandates that tribes be notified upon custody hearings involving "Indian children." 123

Congress's political intentions for the ICWA were clearremedying years of separation of Indian children from their culture, which tarnished Indian culture and sovereignty. Each of the three aforementioned ICWA provisions set Congress's goals for the ICWA and Indian culture in motion. Therefore, Congress not only "talked

117. Jessica Bardill, Tribal Sovereignty and Enrollment Determinations, AM. INDIAN \& ALASKA NATIVE GENETICS RES. CTR., http://genetics.ncai.org/tribalsovereignty-and-enrollment-determinations.cfm [https://web.archive.org/web/2020 0129090559/http://genetics.ncai.org/tribal-sovereignty-and-enrollmentdeterminations.cfm].

118. CRow CREeK Sioux TRIBE Const. art. II, § 2 ("Any child, of one-fourth (1/4) or more Indian blood born to any member of the Tribe who at the birth of such child resided on the reservation shall be entitled to membership.").

119. CherokeE NATion CONST. art. IV, $\S 1$ ("All citizens of the Cherokee Nation must be original enrollees or descendants of original enrollees listed on the Dawes Commission Rolls ....”); Bardill, supra note 117 (describing the Cherokee Nation's tribal membership requirement).

120. Bardill, supra note 117 ("A residency rule requires that the tribal member live within, maintain a residence, or have an allotment among the tribal lands .... The Cedarville Rancheria, Modoc County, Cedarville, California appears to be the only U.S. tribe that still maintains a residency requirement, in combination with a lineal descent requirement, for members.").

121. Brackeen v. Bernhardt, 937 F.3d 406, 428 (5th Cir. 2019).

122. 25 U.S.C. $§ 1914$ ("Any Indian child who is the subject of any action for foster care placement or termination of parental rights under State law, any parent or Indian custodian from whose custody such child was removed, and the Indian child's tribe may petition any court of competent jurisdiction to invalidate such action upon a showing that such action violated any provision of sections 1911, 1912, and 1913 of this title.").

123. 25 U.S.C. § 1912(a) ("[W] here the court knows or has reason to know that an Indian child is involved, the party seeking the foster care placement of, or termination of parental rights to, an Indian child shall notify the parent or Indian custodian and the Indian child's tribe ...."). 
the talk" but also "walked the walk" by designing the ICWA to reflect their political rather than racial purposes.

ii. Legislative History

The ICWA's legislative history bolsters the argument that the ICWA's "Indian child" definition is a political classification. Prior to the ICWA's passage, Congress discussed and documented the importance of protecting Indian children and the Indian community, ${ }^{124}$ noting that Indian children are placed in foster care or in adoptive homes five times more frequently than non-Indian children, sometimes due to ignorance of Indian familial cultural values and social norms. ${ }^{125}$ A House Report discusses the circumstances that affect Indians, which inspired legislative action through the ICWA. ${ }^{126}$ Similarly, a Senate Hearing reviewing the implementation of the ICWA echoes the House Report statements, confirming the purpose of the ICWA is to protect Indian children as well as ongoing traditions and cultures of the tribes and families. ${ }^{127}$ As aforementioned in the discussion of the statutory text, Congress delegated Indian tribes the right to define what constitutes an "Indian child," and therefore, the statute does not racially classify all children that maintain Indian blood or Indian ancestry as "Indian children." Thus, Senate and House discussion regarding the protection of "Indian children" is not race-based, but political because the legislative materials, like the ICWA's statutory text, discuss "Indian children" with the definitional understanding that the ICWA applies only to those children that fit within the ICWA's definition of "Indian child."

Further, the House Report documents that the Committee of Interior and Insular Affairs and Department of Justice considered the potential Fifth Amendment Equal Protection issue regarding the ICWA's definition of "Indian child" before the ICWA was enacted. Then Assistant Attorney General Patricia M. Wald raised a series of potential concerns regarding the ICWA to the House Committee of Interior and Insular Affairs, including whether the "Indian child" definition was a racial classification and, therefore, subject to strict scrutiny. However, Wald concluded that:

124. H.R. REP. NO. 95-1386, at 9-10 (1978).

125. Id.

126. Id. at 8-10.

127. Oversight on the Implementation of the Indian Child Welfare Act of 1978: Hearing Before the S. Comm. on Indian Affairs, 98th Cong. 1-2 (1984) (statements by Senator Mark Andrews, Chairman, S. Comm. on Indian Affairs and John W. Fritz, Deputy Assistant Secretary for Indian Affairs, Bureau of Indian Affairs). 
[t]his problem has been, for the most part, eliminated in the subcommittee draft, which defines 'Indian child' as 'any unmarried person who is under age 18 and is either (a) a member of an Indian tribe or (b) eligible for membership in an Indian tribe and is the biological child of a member of an Indian tribe.' 128

It is telling that the legislators and the Department of Justice considered but dismissed the potential Fifth Amendment equal protection issue because it shows they did not think it was a valid concern. The Fifth Circuit should follow Wald's lead, finding the ICWA's definition of "Indian child" as a political, not racial, classification.

\section{iii. Prior Case Law that Supports the Fifth Circuit's Decision}

Beyond Brackeen v. Bernhardt, no other cases have decided whether the ICWA's definition of "Indian child" is a racial classification. ${ }^{129}$ The U.S. Supreme Court has, however, addressed issues regarding racial classifications, specifically in Morton $v$. Mancari and Rice $v$. Cayetano, which support finding that the definition of "Indian child" is politically-based.130 As aforementioned, Mancari and Rice present two different holdings, and Mancari controls in Brackeen.

In Morton v. Mancari, plaintiffs alleged that employment preferences for qualified Indians in the BIA, as provided in the IRA of 1934, constituted race-based classifications and discrimination, violating the Fifth Amendment's Due Process Clause. ${ }^{131}$ The Court disagreed with the plaintiffs, holding the BIA Indian hiring preference was a political classification, subject to rational basis review. ${ }^{132}$ To justify the holding, the Court examined the legislative history behind the hiring preferences, determining the purpose was to "give Indians a greater participation in their own self-

128. H.R. REP. No. 95-1386, at 39 (1978).

129. But see A.D. by Carter v. Washburn, 2017 WL 1019685, *1-2, 11 (2017) ("[A]dult Plaintiffs and those who have undertaken to speak for the child Plaintiffs attempt to challenge parts of the [ICWA] as unconstitutional racial discrimination .... [A]ll of the pending motions to dismiss the Amended Complaint will be granted, and the Amended Complaint will be dismissed for lack of jurisdiction and lack of standing.").

130. See Rice v. Cayetano, 528 U.S. 495 (2000); Morton v. Mancari, 417 U.S. 535 (1974).

131. Mancari, 417 U.S. at 537.

132. Id. at $554-55$. 
government; to further the Government's trust obligation toward the Indian tribes; and to reduce the negative effect of having nonIndians administer matters that affect Indian tribal life." 133 Thus, the Court found that the tribal sovereignty goal behind the BIA hiring preference aligns with political classifications. ${ }^{134}$ Like the Mancari BIA hiring preference, the ICWA's "Indian child" definition implicates tribal sovereignty. Without culturally connected Indian youth, tribes will cease to exist, undermining the existence of tribal sovereignty. The ICWA's purpose of preserving Indian culture should, therefore, align with political classifications.

Additionally, like the ICWA's "Indian child" definition, the Mancari hiring preference was enacted as part of a federal act, the IRA of 1934. ${ }^{135}$ A court holding that either the BIA Indian hiring preference or the ICWA's "Indian child" definition are racial classifications would completely overturn both Acts, not solely challenged provisions. ${ }^{136}$ Even further, as the courts in Mancari and Brackeen state, overturning the ICWA as a race-based classification would call into question an entire Title of the U.S. Code, and damage the federal government's relations with Indians as it calls into question Indian welfare altogether. ${ }^{137}$

Congress enacted the IRA and the ICWA due to the "belief that institutional changes were required." 138 Both Acts were a response to U.S. governmental behavior that exploited and destroyed Indian interests. ${ }^{139}$ Like the Mancari BIA hiring preference, which was established with the goal to improve Indian welfare through increased sovereignty, the ICWA was established to preserve Indian culture through future generations of children. Thus, the ICWA's definition of "Indian child" and the BIA hiring preference were enacted for reasons beyond race. ${ }^{140}$

The Mancari Court noted that the BIA Indian hiring preference statute is a "provision applying to a very specific

133. Id. at $541-42$.

134. Id. at 555 .

135. Id. at 542 .

136. Brackeen v. Bernhardt, 937 F.3d 406, 426 (5th Cir. 2019) (quoting Mancari, 417 U.S. at 552)

137. Id.

138. Mancari, 417 U.S. at 553.

139. Id. at 541 (stating that the purpose of the BIA Indian hiring preference was to instill greater Indian participation in their own government); see also H.R. REP. No. 95-1386 (1978), at 8 (stating the purpose of the ICWA).

140. Mancari, 417 U.S. at 554 ("Here, the preference is reasonably and directly related to a legitimate, nonracially based goal."). 
situation"-protecting tribal sovereignty. ${ }^{141}$ Although the ICWA does not explicitly justify its enactment in relation to Indian tribal government sustainability, protecting and preserving Indian culture through Indian children is effectively related to tribal sovereignty. Indian children are future tribal leaders. Without Indian children connected to their Indian tribes, tribal sovereignty is temporary. So, the ICWA's goal to preserve and cultivate Indian culture is political.

Unlike the Mancari BIA Indian hiring preference, which is limited to Indians applying for BIA positions, the ICWA's "Indian child" definition is more encompassing. ${ }^{142}$ This broader definition, however, should not be determinative for two reasons. First, the BIA Indian hiring preference and the ICWA only apply to federally recognized tribes. ${ }^{143}$ There are only 574 federally recognized tribes. ${ }^{144}$ The exact number of non-federally recognized Indian tribes is unknown, but the number is substantial. ${ }^{145}$ In fact, in 2012, the U.S. Government Accountability Office (GAO) reported the existence of around 400 non-federally recognized tribes. ${ }^{146}$ Accordingly, the ICWA, like Mancari, "operates to exclude many individuals who are racially to be classified as 'Indians."' 147 Second, the Fifth Circuit notes in Brackeen that the "Indian child" definition is not based solely on race or tribal ancestry because the definition refrains from defining tribal membership requirements. ${ }^{148}$ Instead, tribes have the right to form their own membership laws. ${ }^{149}$ Thus, federally recognized tribes may extend membership to any child

141. Id. at 550 .

142. See 25 U.S.C. § 1903(4) (defining "Indian child" as "any unmarried person who is under age eighteen and is either (a) a member of an Indian tribe or (b) is eligible for membership in an Indian tribe and is the biological child of a member of an Indian tribe").

143. Mancari, 417 U.S. at 553 n.24 (stating the BIA Indian hiring preference applies "only to members of 'federally recognized' tribes"); see also 25 U.S.C. § 1903(8) (defining "Indian tribe").

144. See Tribal Nations \& the United States: An Introduction, NAT'L Cong. OF AM. INDIANS, http://www.ncai.org/about-tribes [https://perma.cc/JEB4-W8QW].

145. Christopher M. Drake, From Invisibility to Liminality: The Imposition of Identity Among Non-federally Recognized Tribes Within the Federal Acknowledgement Process 15 (Jan. 5, 2018) (unpublished M.A. thesis, City University of New York) (on file with CUNY Academic Works) ("The exact number of non-federally recognized tribes is not known. According to Russell Thornton's analysis of the 1990 census, only $60 \%$ of those identifying as American Indian belonged to a federally recognized tribe.").

146. Id. at 15.

147. Mancari, 417 U.S. at 555 n.24.

148. Brackeen v. Bernhardt, 937 F.3d 406, 428 (5th Cir. 2019); see also 25 U.S.C. $\S 1903(4)$.

149. See discussion supra note 115; 25 U.S.C. $§ 1903(4)$. 
they wish, whether or not the child has Indian blood. 150 In sum, the ICWA's "Indian child" definition should be considered a political classification because it aligns with Mancari.

In Rice $v$. Cayetano, plaintiffs claimed that a Hawaii statute, which only allowed "Hawaiians" 151 the right to vote for state trustees of the Office of Hawaiian Affairs (OHA), violated the Fifteenth Amendment and the Fourteenth Amendment's Equal Protection Clause. ${ }^{152}$ The Court held the Hawaii election preferences violated the Fifteenth Amendment. Further, the Court refrained from acknowledging a Fourteenth Amendment Equal Protection violation, yet effectively applied a Fourteenth Amendment analysis, insisting that "[t]he State's electoral restriction enacts a race-based voting qualification."153 The Rice holding sets a new limitation on political classifications that implicate race: If political classifications are employed in democratic electoral processes, the classification, even if presenting a previously non-suspect classification, will be considered a suspect race-based classification and violate the Fifteenth Amendment. ${ }^{154}$ Therefore, Rice complicates political classifications, forcing analysis of the activity in which the racial group is engaged and raising uncertainty about the future protection that racial groups, like Indians, will be afforded through political classifications.

The Rice holding does not control Brackeen for two reasons. First, the definitions of "Native Hawaiian" and "Hawaiian" in Hawaii's voting preference, unlike the ICWA's definition of "Indian child," immediately excluded all individuals who did not fit into the ancestral classification from voting. ${ }^{155}$ As discussed in further detail above in the "Statutory Text" section, 156 the ICWA's definition of "Indian child" operates much differently, allotting each Indian tribe discretion in their membership eligibility requirements. ${ }^{157}$ The ICWA's definition invites Indian tribes to evaluate who they view

150. Brackeen, 937 F.3d at 428.

151. Ellen D. Katz, Race and the Right to Vote After Rice v. Cayetano, 3 MiCH. L. REV. 491, 497 (2000) (defining "Native Hawaiian" as "any descendant of not less than one-half part of the blood of the races inhabiting the Hawaiian Islands previous to $1778 ”)$.

152. Rice v. Cayetano, 528 U.S. 495, 522 (2000).

153. Id. at 517 .

154. Id. at $495-96$.

155. Id. at 514-17 ("Ancestry can be a proxy for race . . . Ancestral tracing of this sort achieves its purpose by creating a legal category which employs the same mechanisms, and causes the same injuries, as laws or statutes that use race by name.").

156. See supra section II.B.i.

157. 25 U.S.C. $§ 1903(4)$. 
as an "Indian child." 58 Second, the Court dismissed the State's argument that the Hawaii voting preference should receive the same political classification that the Indian hiring preference in Mancari was assigned. The Court acknowledged that the Court and Congress have a long history of recognizing special status and preferences for Indians, and the Court displays hesitancy to apply that special status-particularly the political classification-to Hawaiians and Native Hawaiians. 159 Unlike Rice, Brackeen addresses an issue related to Indians, ${ }^{160}$ and the Court has historically allotted special preferences for Indians. Thus, Mancari, not Rice, should control Brackeen, and the Court should hold that the ICWA's definition of "Indian child" is a political classification subject to rational basis review.

In conclusion, the Fifth Circuit's original holding in Brackeen $v$. Bernhardt was correct. The ICWA's statutory text, legislative history, and precedent all support the finding that the ICWA's definition of "Indian child" is a political classification. Upon rehearing the case, the Fifth Circuit should affirm its prior holding, classifying the ICWA's "Indian child" definition as political.

\section{A Call to Congress: The ICWA's "Indian Child" Definition Deserves to Be Revisited}

The ICWA's definition of "Indian child" has not been amended since enactment in $1978 .{ }^{161}$ Congress should revisit the ICWA to improve the effectiveness of the statute. Protecting Indian culture should remain at the forefront of discussion, but everyoneRepresentatives, Senators, social workers, and Indians-should contribute to reach an improved ICWA. The ICWA must better serve the interests of Indian children. There must be a preferable solution that offers: 1) continued preservation of Indian culture; 2)

158. $I d$

159. Rice, 528 U.S. at 518-19 (describing Congress' long history and ability to afford Indians special treatment under the law).

160. Native Hawaiians are not considered "Indians" in the eyes of the federal government, which does not maintain any government-to-government relationship with Native Hawaiians as it would with a federally-recognized tribe. See Michael Grass, As Feds Hold Hearings, Native Hawaiians Press Sovereignty Claims, RouTE FIFTY (Aug. 12, 2014), https://www.route-fifty.com/management/2014/08/hawaiisovereignty-department-interior-hearings/91247/ [https://perma.cc/X4KH-SEEE]; Press Release, U.S. Dep't of the Interior, Interior Considers Procedures to Reestablish a Government-to-Government Relationship with the Native Hawaiian Community (Apr. 26, 2016), https://www.doi.gov/news/pressreleases/interiorconsiders-procedures-to-reestablish-a-government-to-government-relationshipwith-the-native-hawaiian-community [https://perma.cc/7UCM-GABP].

161. 25 U.S.C. $§ 1901$. 
greater deference to Indian parents' regarding how their children are raised; and 3) Indian children more avenues for adequate homes. This Note is a call to reexamine, amend, and advocate for an improved "Indian child" definition and an improved ICWA. This section provides themes to be considered upon revisiting the ICWA.

\section{A. Burden of Proof}

The ICWA imposes a higher burden of proof to terminate parental rights of Indian children from troubling home situations than non-Indian children from similar situations. ${ }^{162}$ The ICWA requires a finding "supported by evidence beyond a reasonable doubt, including testimony of qualified expert witnesses, that the continued custody of the child by the parent or Indian custodian is likely to result in serious emotional or physical damage to the child" to terminate parental rights of an "Indian child." 163 Unlike the burden of proof required under the ICWA, in Santosky v. Kramer, the U.S. Supreme Court refused to apply the "beyond a reasonable doubt" requirement found in the ICWA to non-Indian cases because "the psychiatric evidence ordinarily adduced at commitment proceedings is rarely susceptible to proof beyond a reasonable doubt." 164 Because of the broadness of the ICWA's definition of "Indian child," many Indian children struggle from limited protection under the ICWA. Thus, as Congress reevaluates the ICWA and its definition of "Indian child," Congress should consider the high burden of proof required to remove Indian children from troubling situations. But Congress must also remember that these higher burdens of proof regarding removal of "Indian children" were implemented in response to the disproportionately high number of Indian children being removed from their families, threatening Indian culture. ${ }^{165}$

\footnotetext{
162. Compare 25 U.S.C. $§ 1912$ (e) (stating that the placement of an "Indian child" in foster care requires a finding of "clear and convincing evidence, including testimony of qualified expert witnesses, that the continued custody of the child by the parent or Indian custodian is likely to result in serious emotional or physical damage to the child"), and $\S 1912(\mathrm{f})$ (stating that termination of parental rights over an "Indian child" requires the same finding, but "supported by evidence beyond a reasonable doubt," with Santosky v. Kramer, 455 U.S. 745, 769 (1982) (declining to adopt the "beyond a reasonable doubt" standard to terminate non-Indian parental rights).

163. 25 U.S.C. $§ 1912(\mathrm{f})$.

164. Santosky, 455 U.S. at 768-69.

165. S. REP. NO. 95-597, at 1 (1977).
} 


\section{B. Geography and Blood Quantum}

Congress should reconsider the ICWA's definition of "Indian child" in light of tribes' changing tribal enrollment requirements and geographic locations. There are 574 federally recognized American Indian tribes. ${ }^{166}$ Of the nearly 5.2 million Indians in the U.S., as of 2010, only about 22 percent lived on Indian reservations or other trust lands, leaving 78 percent of Indians geographically distanced from their tribal lands. ${ }^{167}$ Regardless of their geographic location, each child who qualifies as an "Indian child" remains subject to the ICWA because the child's tribe always has a right to intervene at any point or invalidate a termination of parental rights and foster care placement.168 Thus, children with little to no preexisting ties to their Indian heritage are subject to the ICWA's stringent restrictions.

Not all Indian tribes have blood quantum enrollment requirements, ${ }^{169}$ and each Indian tribe has the right to determine the minimum blood quantum requirement should they choose to implement the requirement. ${ }^{170}$ Due to high levels of interracial marriages and relationships throughout the years, Indian blood quanta have weakened, ${ }^{171}$ excluding countless Indians from tribal enrollment as they are unable to meet their particular tribe's specific blood quantum enrollment requirements. In response, tribes have begun discussions regarding loosening tribal enrollment requirements to allow more Indians to qualify, implicating individuals geographically distanced from tribes. ${ }^{172}$ While

166. See Tribal Nations \& the United States: An Introduction, supra note 144.

167. See Living Conditions, supra note 113.

168. 25 U.S.C. $§ 1911(c)$.

169. See, e.g., CherokeE NATiOn Const. art. IV, $\S 1$ ("All citizens of the Cherokee Nation must be original enrollees or descendants of original enrollees listed on the Dawes Commission Rolls ....").

170. Abi Fain \& Mary Kathryn Nagle, Close to Zero: The Reliance on Minimum Blood Quantum Requirements to Eliminate Tribal Citizenship in the Allotment Acts and the Post-adoptive Couple Challenges to the Constitutionality of ICWA, 43 Mitchell HAMLine L. REV. 801, 805 (2017).

171. See Haeyoun Park, Who Is Marrying Whom, N.Y. Times (Jan. 29, 2011), https://archive.nytimes.com/www.nytimes.com/interactive/2011/01/29/us/20110130 mixedrace.html?ref=us [https://perma.cc/93PU-BZ6C] (demonstrating that Native Americans have the highest rate of interracial marriage of all studied racial groups).

172. See Nicole MartinRogers \& Tom Gillaspy, Minnesota Chippewa Tribe Population Projections: Methodology Report, WILDER RESCH. 8 (May 2014), https://www.mnchippewatribe.org/pdf/MCT\%20Methodology\%20Report.pdf

[https://perma.cc/R8XV-RHQG]. The Minnesota Chippewa Tribe conducted a study to examine population projections and membership requirements. The study found that over 28,000 individuals are "multi-race American Indian with some relationship 
expanding tribal enrollment requirements may be beneficial to tribes and some newly qualifying individuals, expansion will likely place more Indian children under the ICWA umbrella from more remote geographic locations. ${ }^{173}$ Therefore, the less stringent tribal enrollment requirements are, the more remote connections individuals will have to their eligible tribes. ${ }^{174}$ Challenges to the ICWA regarding children with minute blood quantum levels and few ties to tribes will likely increase upon tribal enrollment expansions as more children will fall under the ICWA umbrella. Thus, Congress must consider trends in Indians' geographic locations as well as implications for expansive tribal enrollment requirements upon revisiting the ICWA's definition of "Indian child."

Conversely, Congress should also consider that as more Indians are distanced further from their tribes, both due to geography and blood quantum, there is a greater need than ever to retain the broad definition of "Indian child" to protect Indian culture.

\section{The ICWA's Deterrence Effect}

The ICWA enforces a preference system for adopting or fostering Indian children that aims to place the children with other Indian families. ${ }^{175}$ However, too often, there are not enough Indian foster families across the nation, forcing tribes to place the children in non-Indian homes. ${ }^{176}$ Unfortunately, the difficulties the ICWA

to the Chippewa" who live in the five-state area (Montana, North Dakota, Minnesota, Wisconsin, and Michigan) but who are not enrolled Chippewa members. It is projected that about $50 \%$ of these 28,451 non-enrolled individuals are likely eligible under the tribe's current one-quarter blood quantum enrollment requirement. If, however, the Minnesota Chippewa Tribe lowers the enrollment minimum to a oneeighth requirement, about $75 \%$ of these individuals would likely qualify for enrollment. Chippewa tribal members recognize that their culture cannot be carried on without a tribe, thus the Chippewa Tribe is considering its options.

173. $I d$. at 7 (stating that if the Minnesota Chippewa tribe expands tribal enrollment requirements, the number of Indian adults and children implicated within the five-state area could dramatically increase).

174. See Fain \& Nagle, supra note 170, at 810 (quoting Complaint, A.D. v. Washburn, 2017 WL 1019685 (D. Ariz. July 26, 2017) (No. 2:15-CV-01259-NVW)) ("[I]n many instances, children with only a minute quantum of Indian blood and no connection or ties to the tribe are subject to ICWA and relegated to the tribe's exclusive or concurrent jurisdiction.").

175. 25 U.S.C. $§ 1915$ (a) ("In any adoptive placement of an Indian child under State law, a preference shall be given, in the absence of good cause to the contrary, to a placement with (1) a member of the child's extended family; (2) other members of the Indian child's tribe; or (3) other Indian families.").

176. See Debra Utacia Krol, Inside the Native American Foster Care Crisis Tearing 
imposes on non-Indian individuals adopting Indian children, such as the tribe's unconditional right to intervene in "Indian child" adoptions, deters non-Indian individuals from fostering Indian children. ${ }^{177}$ Therefore, Congress should discuss the ICWA's potential deterrence effect upon fostering Indian children and its potential ramifications on Indian children upon review of the ICWA's "Indian child" definition. During these deliberations, Congress might consider narrowing the ICWA's definition of "Indian child" 178 or amending and limiting the scope of tribal ability to intervene in any foster care or adoption proceeding regarding an "Indian child." 179

\section{Policy Propositions}

Improving the ICWA's definition of "Indian child" should be a joint effort between Indian leaders and Congress. Protecting Indian culture is essential, and the ICWA attempts to act as a protective guide; however, it is flawed. Without sufficient support mechanisms, Indian foster homes, and resources, the statute cannot perform as intended. There must be a better way to ensure protection and preservation of Indian culture while also placing a stronger emphasis on the best interests of Indian children. Without further explanation, Judge Amy Pellman, a family law judge in Los Angeles stated, "some tweaks in the law" might fix the ICWA's challenges. ${ }^{180}$ Although there is consensus that the ICWA is flawed, the mode to remedy the flaws is unclear. What is clear, though, is that jointly, Congress and Indians should review the ICWA's definition of "Indian child" and discuss its positive and negative effects on Indian culture and Indian children.

Families Apart, VICE (Feb. 7, 2018), https://www.vice.com/en_us/article/a34g8j/ inside-the-native-american-foster-care-crisis-tearing-families-apart

[https://perma.cc/6C6Q-P3WA] ("With a disproportionate number of Native kids removed from their homes each year, the need for Native foster homes is huge-and there aren't enough to meet the need. That shortage leads to non-Native foster parents taking in kids from tribal communities. Sometimes, those foster parents decide they want to adopt the foster child even though the law is supposed to prevent virtually all such non-Native adoptions. This has led to nasty fights over custody[.]").

177. In the U.S. Supreme Court's most recent case regarding the ICWA, the Court recognized the ICWA's potential deterrence effect regarding adoption of Indian children and sought to mitigate those negative consequences. Adoptive Couple v. Baby Girl, 570 U.S. 637, 653-54 (2013).

178. 25 U.S.C. $§ 1903(4)$.

179. $\S 1911(\mathrm{c})$.

180. See Gabby Deutch, A Court Battle Over a Dallas Toddler Could Decide the Future of Native American Law, THE ATLANTIC (Feb. 21, 2019), https://www.theatlantic.com/family/archive/2019/02/indian-child-welfare-actsuncertain-future/582628/ [https://perma.cc/V9P3-JN63]. 
The parties may consider the following when discussing potential amendments to the ICWA's definition of "Indian child." If the ICWA's definition of "Indian child" was narrowed by striking or limiting part (b), 181 the "eligibility" provision, Congress might consider publishing a formal document encouraging and requesting the foster care system to work together and form strong alliances with Indian tribes to carry out goals that preserve Indian culture while also acting in the best interests of Indian children. For example, tribes and state and tribal foster care systems can offer Indian cultural education sessions for Indian children placed in non-Indian homes and sessions for non-Indian foster and adoptive parents. These cultural education sessions could teach the children and adults about an Indian child's particular tribal history as well as Indian culture and history more generally. Additionally, the tribes and state and tribal foster care systems could organize support groups or big-brother/big-sister type relationships for Indian children placed with non-Indian parents to explore their cultural ties.

If, however, the definition of "Indian child" is not adapted, Congress might add a provision to the ICWA allowing parents of a qualifying "Indian child" an election right to opt out of the ICWA. A provision of this type relates to the issue presented in Miss. Band of Choctaw Indians v. Holyfield. As aforementioned, in Holyfield, the Indian parents purposefully left the reservation to give birth to their twins in hopes that their children would not be considered domiciled on the reservation and the ICWA would not apply. ${ }^{182}$ Regardless of the parents' purposeful actions to avoid the ICWA, the Court held that the twins, who were adopted by a non-Indian couple, fell subject to the ICWA. ${ }^{183}$ An amendment of this nature would offer parents autonomy over their children's future, which to a certain extent, the ICWA's current form prevents. Additionally, as discussed above, Congress might also consider an amendment that lowers the currently demanding burden of proof the ICWA requires to remove Indian children to temporary foster care and to terminate parental rights. The goal behind these propositions is to sustain the ICWA's emphasis on protecting Indian culture while also finding a happy medium regarding the best interests of Indian children.

181. 25 U.S.C. § 1903(4)(b).

182. Miss. Band of Choctaw Indians v. Holyfield, 490 U.S. 30, 37-39 (1989).

183. Id. at 53 . 
These propositions require more discussion and evaluation; however, they demonstrate ideas aiming to support Indian cultural preservation and improve the ICWA's treatment and applicability to the "Indian child." Again, reviewing and improving the ICWA's definition of "Indian child" must be a joint effort between Indian leaders and Congress.

\section{Conclusion}

American Indians have historically faced cruelty at the hands of the U.S. government comparable to the type of cruelty the U.S. ferociously fought against in World War II. ${ }^{184}$ Addressing the U.S.' past failure to respect and preserve American Indian culture cannot and should not be forgotten. The ICWA works to preserve Indian culture. ${ }^{185}$ Without it, many "[t]ribes fear that invalidating the ICWA on a racial basis has the potential to create a domino effect, bringing down the rest of American Indian law with it." 186 However, the ICWA has faults that require attention. There must be a better solution.

This Note examines a recent Fifth Circuit case, Brackeen $v$. Bernhardt, which challenges the ICWA's definition of "Indian child" on equal protection grounds, claiming the definition is race-based, and therefore, subject to strict scrutiny. 187 The Fifth Circuit correctly overturned the District Court, holding that the ICWA's definition of "Indian child" is a political classification, not a racebased classification, and therefore, subject to rational basis review. ${ }^{188}$ The ICWA's statutory text, legislative history, and precedent indicate that the ICWA's definition of "Indian child" was designed with a particular political purpose: protecting Indian culture and Indian children. The Fifth Circuit's holding that the definition of "Indian child" is a political classification allows Indian children to receive the special protections they deserve. It is, however, the U.S. government's and Indian leaders' responsibilities

184. See Hitler Studied U.S. Treatment of Indians, INDIAN COUNTRY TODAY (Aug. 8, 2016), https://newsmaven.io/indiancountrytoday/archive/hitler-studied-u-streatment-of-indians-pYDkk-692Ei3XkztuwKVhg [https://perma.cc/F3VC-SHAX] (explaining that Hitler studied U.S. policies implemented against Indians as models for how he would treat Jewish people); see also ZIIBIWING CTR. OF ANISHINABE CULTURE \& LIFEWAYS, AMERICAN INDIAN BOARDING SCHOOLS: AN EXPLORATION OF Global EThNic \& CUltural CleANSING 18 (2011) [https://perma.cc/27CY-GVJQ] (describing Hitler's admiration and knowledge of the Indian boarding schools, genocide, and internment camps organized by the U.S.).

185. 25 U.S.C. $\S 1902$ (stating the ICWA's purpose).

186. See Deutch, supra note 180.

187. Brackeen v. Bernhardt, 937 F.3d 406, 425-26 (5th Cir. 2019).

188. Id. at 429 . 
to ensure these special protections do not disadvantage Indian children along the way. I do not have the answer to solve the issues facing the ICWA's definition of an "Indian child." However, growing up in a rural community within twenty miles of two Indian Reservations and observing close friends fostering Indian children, I have seen Indian culture regaining strength through its youth; but I have also seen the ICWA fail to protect Indian children. The conversation regarding the ICWA and the ICWA's definition of "Indian child" must be reignited for the sake of both Indian culture and Indian children. Negative consequences resulting from the ICWA and its definition of "Indian child" will not cease without conversation, decisions, and cooperation. Congress owes this effort to American Indians and their culture. 